\title{
Nonlinear models in the height description of the Rhino sunflower cultivar
}

\author{
Anderson Chuquel Mello ${ }^{1}$ (D) Marcos Toebe ${ }^{2 *}$ (D) Rafael Rodrigues de Souza $^{1}$ (D) \\ João Antônio Paraginski ${ }^{1}$ (D) Junior Carvalho Somavilla ${ }^{3}$ (iD \\ Vinícius Martins ${ }^{3}$ (D) Antônio Carlos Vieira Pinto ${ }^{3}$ (D)
}

'Programa de Pós-graduação em Agronomia, Agricultura e Ambiente, Universidade Federal de Santa Maria (UFSM), Frederico Westphalen, RS, Brasil. ${ }^{2}$ Departamento de Ciências Agronômicas e Ambientais, Universidade Federal de Santa Maria (UFSM), 98400-000, Frederico Westphalen, RS, Brasil. E-mail: m.toebe@gmail.com. "Corresponding author.

${ }^{3}$ Curso de Agronomia, Universidade Federal de Santa Maria (UFSM), Frederico Westphalen, RS, Brasil.

ABSTRACT: Sunflower produces achenes and oil of good quality, besides serving for production of silage, forage and biodiesel. Growth modeling allows knowing the growth pattern of the crop and optimizing the management. The research characterized the growth of the Rhino sunflower cultivar using the Logistic and Gompertz models and to make considerations regarding management based on critical points. The data used come from three uniformity trials with the Rhino confectionery sunflower cultivar carried out in the experimental area of the Federal University of Santa Maria - Campus Frederico Westphalen in the 2019/2020 agricultural harvest. In the first, second and third trials 14, 12 and 10 weekly height evaluations were performed on 10 plants, respectively. The data were adjusted for the thermal time accumulated. The parameters were estimated by ordinary least square's method using the Gauss-Newton algorithm. The fitting quality of the models to the data was measured by the adjusted coefficient of determination, Akaike information criterion, Bayesian information criterion, and through intrinsic and parametric nonlinearity. The inflection points (IP), maximum acceleration (MAP), maximum deceleration (MDP) and asymptotic deceleration $(A D P)$ were determined. Statistical analyses were performed with Microsoft Office Excel ${ }^{\mathbb{}}$ and $R$ software. The models satisfactorily described the height growth curve of sunflower, providing parameters with practical interpretations. The Logistics model has the best fitting quality, being the most suitable for characterizing the growth curve. The estimated critical points provide important information for crop management. Weeds must be controlled until the MAP. Covered fertilizer applications must be carried out between the MAP and IP range. ADP is an indicator of maturity, after reaching this point, the plants can be harvested for the production of silage without loss of volume and quality.

Key words: Helianthus annuus L., Logistic, Gompertz, growth curve.

Modelos não lineares na descrição de altura da cultivar de girassol Rhino

RESUMO: O girassol produz aquênios e óleo de qualidade, além de servir para produção de silagem, forragem e biodiesel. A modelagem de crescimento permite conhecer o padrão de crescimento da cultura e otimizar o manejo. O objetivo deste trabalho foi caracterizar o crescimento da cultivar de girassol Rhino por meio dos modelos Logístico e Gompertz e fazer considerações a respeito do manejo com base em pontos críticos. Os dados utilizados são oriundos de três ensaios de uniformidade com a cultivar de girassol confeiteiro Rhino, conduzidos na área experimental da Universidade Federal de Santa Maria, Campus Frederico Westphalen, na safra 2019/2020. Foram realizadas 14 , 12 e 10 avaliações semanais de altura em 10 plantas, respectivamente, no primeiro, segundo e terceiro ensaio. Os dados foram ajustados em função da soma térmica acumulada. Os parâmetros foram estimados por meio do método dos mínimos quadrados ordinários, usando o algoritmo de Gauss-Newton. A qualidade de ajuste dos modelos aos dados foi medida pelo coeficiente de determinação ajustado, critério de determinação de Akaike, critério bayesiano de informação, e por meio da não linearidade intrínseca e paramétrica. Foram determinados os pontos de inflexão (PI), máxima aceleração (MAP), máxima desaceleração (MDP) e desaceleração assintótica (ADP). As análises estatisticas foram realizadas com Microsoft Office Excel ${ }^{\circledR}$ e o software R. Os modelos descreveram de forma satisfatória a curva de crescimento da altura do girassol, fornecendo parâmetros com interpretações práticas. O modelo Logístico apresenta melhor qualidade de ajuste, sendo o mais adequado para caracterização da curva de crescimento. Os pontos críticos estimados fornecem informações importantes para o manejo da cultura.As plantas daninhas devem ser controladas até o MAP. As aplicações de fertilizantes em cobertura devem ser realizadas entre MAP e IP. O ADP é um indicador de maturidade, após atingir este ponto, as plantas podem ser colhidas para a produção de silagem sem perda de volume e qualidade.

Palavras-chave: Helianthusannuиs L., Logístico, Gompertz, curva de crescimento.

\section{INTRODUCTION}

2

3 Sunflower (Helianthus annuus L.) is an 4 annual broadleaf crop belonging to the Asteraceae family, known worldwide for producing achenes and oil of the highest quality (KOUTROUBAS et al., 2020). This species has a great productive ability, being used for medicinal and ornamental purposes, 
1 silage and forage production, green manure, 2 bioremediation, biofuel production, among others 3 (HESAMI et al., 2015; AMORIM et al., 2020; IRAM 4 et al., 2020).

About $10 \%$ of the world's annual sunflower production is destined for non-oil purposes, this demand being met by confectionery genotypes that are characterized by having greater stature of larger plants and seeds with lower oil contents and higher protein contents (HLADNI et al., 2011). Height of plants is one of the most important characters for confectionery sunflower genotypes (PEKCAN et al., 2015; HLADNI et al., 2016), as it correlates with characters such as stem diameter, number of leaves, chapter diameter, seed yield per plant and oil and protein contents (PIVETTA et al., 2012; YANKOV \& TAHSIN, 2015).

Low water availability and incidence of pests are responsible for lower productivity and retraction of sunflower's planted area (CONAB, 2020). One way to overcome these difficulties is to seek greater knowledge about how the cropresponds to the environment in which it is inserted, aiming to adapt and improve management techniques through growth models. Therefore, modeling becomes an indispensable tool to characterize plant growth and development (STRECK et al., 2008).

Nonlinear models have been used to characterize the growth of many crops such as coffee (FERNANDES et al., 2014), cocoa (MUNIZ et al., 2017), tomato (SARI et al., 2019), sugar cane (JANE et al., 2020), among others. Nonlinear, Logistic and Gompertz models are the most used since they provide a better fit compared to linear models in growth studies and for having parameters with practical and biological interpretation (MAZZINI et al., 2003). Both models have a sigmoidal shape ("S" shape), presenting a slow initial growth, increasing until reaching the so-called inflection point, and decreasing again until reaching its asymptotic limit (MISCHAN \& PINHO, 2014). The Logistic model is characterized for being symmetrical in relation to the inflection point, that is, at the inflection point, $50 \%$ of the upper asymptote is reached, while in the Gompertz model the inflection point is reached at $37 \%$ of the upper asymptote, where there is a change in the concavity of the curve and the growth rate starts to decrease (FERNANDES et al., 2014; JANE et al., 2020).

The critical points in non-linear models has been used in many studies in agricultural sciences, as it provides relevant information on crop management. In this sense, CARINI et al. (2020), used inflection points, maximum acceleration and maximum deceleration to make inferences about the growth and behavior of three lettuce cultivars. In turn, KLEINPAUL et al. (2019), besides using inflection points, maximum acceleration and maximum deceleration, made use of the asymptotic deceleration point to describe the accumulation of fresh and dry rye mass. Therefore, this study was to characterized the growth of the confectionary sunflower cultivar Rhino by nonlinear Logistic and Gompertz models and to make considerations regarding management based on critical points of the models.

\section{MATERIALS AND METHODS}

During the 2019/2020 agricultural harvest, threeuniformity trials(experiments withouttreatments) were carried out with sunflower (Helianthus annuus L.) in the experimental area of the Federal University of Santa Maria-FredericoWestphalen-RS-Brazil. The area's soil is classified as Red Latosol and the climate is characterized by Köppen as Cfa (ALVARES et al., 2013). Sowing was performed on September 23, 2019 (First), October 7, 2019 (Second) and October 23, 2019 (Third) using the confectionary sunflower cultivar Rhino, with $0.5 \mathrm{~m}$ spacing between rows and $0.33 \mathrm{~m}$ between plants.

Sowing was performed manually with two seeds per point and subsequent thinning to obtain the recommended population of 60,000 plants.ha ${ }^{-1}$. Each trial consisted of a strip of $250 \mathrm{~m}^{2}$, containing 10 rows $(5 \mathrm{~m})$ per $50 \mathrm{~m}$ in length. Fertilization was carried out according to soil analysis and recommendations for the crop (CQFS, 2016), with $10 \mathrm{~kg} \cdot \mathrm{ha}^{-1}$ of $\mathrm{N}$, $70 \mathrm{~kg} \cdot \mathrm{ha}^{-1}$ of $\mathrm{K}_{2} \mathrm{O}$ and $60 \mathrm{~kg} \cdot \mathrm{ha}^{-1}$ of $\mathrm{P}_{2} \mathrm{O}_{5}$ applying at sowing and $50 \mathrm{~kg} \cdot \mathrm{ha}^{-1}$ of $\mathrm{N}$ at 30 days after emergence. All cultural treatments were performed uniformly in the experimental area. Height was assessed weekly, destructively on 10 plants per trial, collected at random, with 14, 12 and 10 assessments for the first, second and third trials, respectively.

Height data were adjusted according to the accumulated thermal sum (TSa), calculated according to the method of GILMORE \& ROGERS (1958) and ARNOLD (1959), with a base temperature of $4.2{ }^{\circ} \mathrm{C}$ according to determinations made by SENTELHAS et al. (1994).Logistic and Gompertz models were used according to the equations $y i=\frac{a}{1+e^{\left(b-c x x_{i}\right)}}+\varepsilon_{i}$ and $y i=a e^{\left[-e^{\left(b-c x x_{i}\right)}\right]}+\varepsilon_{i}$, respectively, where $y i$ represents the observed height values (dependent variable) for $\mathrm{i}=1,2, \ldots, n$ observations, and $x_{i}$ is the $\mathrm{i}^{\text {th }}$ time measurement of the independent 
1 variable (TSa), $a$ represents the asymptotic value of the

2 dependent variable, $b$ is a location parameter, important

3 for maintaining the sigmoidal shape of the modeland

4 and associated with the abscissa of the inflection point,

$5 c$ is related to the growth rate, the higher the value of

6 parameter $c$, the shorter the time required to reach the

7 asymptote $(a)$ and $\varepsilon_{i}$ corresponds to the random error,

8 assumed to be independently and identically distributed

9 following a normal distribution with a mean zero and

0 constant variance, that is, $\varepsilon_{i} \sim N\left(0, \sigma^{2}\right)$. the normality, homogeneity a assumptions, as the values of the Shapiro-Wilk, DurbinWatson and Breusch-Pagan tests had a statistical $\mathrm{p}$-value $>0.05$. These results are in agreement with those of CARINI et al. (2020) when using nonlinear models to describe the growth of lettuce cultivars. The Gompertz model stim or greater height asymptotic values (parameter $a$ ) for the third trial and the fourth situation (All) using all trial, compared to the Logistic model (Table 1). The Logistic model estimates higher $b$ values for the second and third trials and the Gompertz model estimates higher values of parameter $b$ for the first trial. The $c$ values estimated for Logistics were higher in all trials.

When comparing the Logistic model between trials, the estimates of the first and third trials are the same for all parameters, based on the overlapping of confidence intervals (CI), used by WHEELERN et al. (2006), BEM et al. (2017) and CARINI et al. (2020). According to these authors, when at least one parameter estimate is contained within the CI of the other, the difference is not significant. So, the estimated values of $197.357 \mathrm{~cm}$ and $202.866 \mathrm{~cm}$ for $a$, respectively, in the first and third trials did not differ. The estimates for the second trial are for plants with reduced height asymptotic $(192.058 \mathrm{~cm})$, but with no significant differences for $b$ and $c$ in relation to the first and third trials (Table 1).

Gompertz model estimated different $a$ and $b$ parameters for all trials (Table 1). The asymptotic height values were 201.088, 195.617 and $213.101 \mathrm{~cm}$; respectively for the first, second and third trial. The $b$ parameter differed between the trials, being more variable for the Gompertz model. SARI et al. (2019) used nonlinear models to describe the accumulated tomato production in successive harvests and named $b$ as a "scale parameter", associated with the degree of maturation (initial production), however, this approach does not apply to sunflower height growth. According to CARINI et al. (2020), the estimate of $b$, in theory, provides a concept of the ratio between the initial values and the amount left to reach the asymptote.

The values of parameter $c$, related to precocity (DIEL et al., 2021), are not different between the trials for Logistics and Gompertz, but they are different between the models, where Logistic model estimates are higher (Table 1). The nondifference of $c$ between trials can be explained by the use of the same cultivar. The models generated using data from the three trials estimate asymptotic height values of $196.364 \mathrm{~cm}$ for Logistics and $200.757 \mathrm{~cm}$ for Gompertz, a similar pattern to what we have when the parameters were estimated for the third trial, where the Gompertz values are higher .
1

2

3

4

5

6

7

8

9

10

11

12

13

14

15

16

17

18

19

20

21

22

23

24

25

26

27

28

29

30

31

32

33

34

35

36

37

38

39

40

41

42

43

44

45

46

47

48

49

50

51

52

53

Ciência Rural, v.52, n.3, 2022. 
Table 1 - Estimation of parameters $a, b$ and $c$, lower limit (LL) and upper limit (UL) of the confidence interval (CI ${ }_{95 \%}$ ), Adjusted coefficient of determination $\left(\mathrm{R}_{\mathrm{a}}^{2}\right.$ ), Akaike information criterion (AIC), Bayesian information criterion (BIC), intrinsic curvature measurements (IN), parameter effect curvature measurements (PE), maximum acceleration point (MAP), inflection point (IP), maximum deceleration point (MDP) and asymptotic deceleration point (ADP), of the Logistic and Gompertz models for the trials (First, Second, Third and All) as a function of the accumulated thermal sum $\left({ }^{\circ} \mathrm{Cd}\right)$ of the Rhino sunflower cultivar.

\begin{tabular}{|c|c|c|c|c|c|c|c|c|c|}
\hline & & \multicolumn{4}{|c|}{ 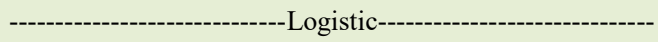 } & \multicolumn{4}{|c|}{------------------------------'Gompertz--------------------------- } \\
\hline & & First & Second & Third & All & First & Second & Third & All \\
\hline \multirow{3}{*}{$a$} & LL & 194.084 & 188.080 & 196.410 & 193.813 & 196.824 & 190.557 & 203.486 & 197.443 \\
\hline & Mean & $197.357^{\mathrm{aA}(1)}$ & $192.058^{\mathrm{bA}}$ & $202.866^{\mathrm{aA}}$ & $196.364^{\mathrm{A}}$ & $201.088^{\mathrm{aA}}$ & $195.617^{\mathrm{bA}}$ & $213.101^{\mathrm{cB}}$ & $200.757^{\mathrm{B}}$ \\
\hline & UL & 200.718 & 196.094 & 209.978 & 198.936 & 205.419 & 200.954 & 223.804 & 204.145 \\
\hline \multirow{3}{*}{$b$} & LL & 4.137 & 4.656 & 4.337 & 4.504 & 10.035 & 2.658 & 2.289 & 2.550 \\
\hline & Mean & $4.507^{\mathrm{aA}}$ & $5.168^{\mathrm{aA}}$ & $4.776^{\mathrm{aA}}$ & $4.770^{\mathrm{A}}$ & $13.091^{\mathrm{aB}}$ & $3.011^{\mathrm{bB}}$ & $2.586^{\mathrm{cB}}$ & $2.737^{\mathrm{B}}$ \\
\hline & UL & 4.920 & 5.740 & 5.266 & 5.056 & 17.372 & 3.417 & 2.928 & 2.934 \\
\hline \multirow{3}{*}{$c$} & LL & 0.0060 & 0.0069 & 0.0057 & 0.0064 & 0.0039 & 0.0045 & 0.0034 & 0.0042 \\
\hline & Mean & $0.0066^{\mathrm{aA}}$ & $0.0076^{\mathrm{aA}}$ & $0.0064^{\mathrm{aA}}$ & $0.0068^{\mathrm{A}}$ & $0.0043^{\mathrm{aB}}$ & $0.0051^{\mathrm{aB}}$ & $0.0039^{\mathrm{aB}}$ & $0.0045^{\mathrm{B}}$ \\
\hline & UL & 0.0072 & 0.0085 & 0.0071 & 0.0072 & 0.0048 & 0.0057 & 0.0045 & 0.0048 \\
\hline $\mathrm{R}_{\mathrm{a}}^{2}$ & & 0.972 & 0.968 & 0.967 & 0.966 & 0.969 & 0.963 & 0.964 & 0.963 \\
\hline AIC & & 1111.840 & 967.070 & 813.306 & 2917.444 & 1131.775 & 990.471 & 825.891 & 2966.234 \\
\hline $\mathrm{BIC}$ & & 1123.606 & 978.220 & 823.727 & 2932.988 & 1143.541 & 1001.621 & 836.312 & 2981.779 \\
\hline IN & & 0.069 & 0.082 & 0.073 & 0.045 & 0.095 & 0.108 & 0.103 & 0.060 \\
\hline PE & & 0.145 & 0.172 & 0.236 & 0.101 & 0.203 & 0.240 & 0.421 & 0.143 \\
\hline \multirow{2}{*}{ MAP } & $\mathrm{x}$ & 486.545 & 504.587 & 542.138 & 507.958 & 368.150 & 403.643 & 410.909 & 394.881 \\
\hline & $\mathrm{y}$ & 41.707 & 40.587 & 42.871 & 41.494 & 14.678 & 14.281 & 15.557 & 14.657 \\
\hline \multirow{2}{*}{ IP } & $\mathrm{x}$ & 687.964 & 677.780 & 749.283 & 701.958 & 590.247 & 594.189 & 655.954 & 609.294 \\
\hline & $\mathrm{y}$ & 98.679 & 96.029 & 101.433 & 98.176 & 73.784 & 71.786 & 78.202 & 73.676 \\
\hline \multirow{2}{*}{ MDP } & $\mathrm{x}$ & 889.384 & 850.972 & 956.427 & 895.958 & 812.423 & 785.011 & 900.900 & 823.708 \\
\hline & $\mathrm{y}$ & 155.657 & 151.477 & 160.002 & 154.863 & 137.170 & 133.491 & 145.338 & 136.949 \\
\hline \multirow{2}{*}{$\mathrm{ADP}$} & $\mathrm{x}$ & 1038.632 & 979.566 & 1109.068 & 1039.638 & 1005.121 & 950.126 & 1113.693 & 1009.815 \\
\hline & $\mathrm{y}$ & 179.262 & 174.410 & 187.237 & 178.339 & 170.247 & 165.637 & 180.441 & 169.998 \\
\hline
\end{tabular}

${ }^{(1)}$ Comparison of parameter estimates $(a, b$ and $c$ ) between trials and between models, based on the overlapping of confidence intervals $\left(\mathrm{CI}_{95 \%}\right)$. Averages followed by the same lowercase letter do not differ between trials for the same model. Averages followed by the same capital letter do not differ for the same trial between models. 3 model best described the growth of sunflower plants 4 in height in the four situations studied (Table 1). For 5 all situations, differences between Logistical and

6 Gompertz models were not verified when observing

$7 \mathrm{R}^{2}$ in isolation, as the values are similar, varying from

80.963 to 0.972 , which showed that both models adjust

9 to all situations, and emphasizes the need for more

10 than one criterion for comparison. The differentiation

11 can be made by observing the other evaluators. The

12 Logistic model presented the lowest values of AIC,

13 BIC, IN and PE for the three trials and also for the fourth situation in which all data are used. Models that present higher values of $\mathrm{R}^{2}$ and lower values of AIC, BIC, IN and PE, should be preferable for growth description (ZEVIANI, 2012; FERNANDES et al., 2014; JANE et al., 2020). The $\mathrm{R}^{2}$, AIC and BIC estimators cannot be compared between trials of the same model because they depended on the number of parameters and observations made (AKAIKE, 1974; SCHWARZ, 1978; SEBER, 2003), and as already mentioned, both models have three parameters, but 14, 12 and 10 evaluations were performed for the first, second and third trials, respectively. So, the number of observations between trials is unbalanced. 
The Logistics model showed a better fit to the data based on the lower values of the AIC, BIC, IN and PE evaluators (Table 1) and on the response of the curves on the data (Figure 1 A-D). Furthermore, the adjustment of Logistics and Gompertz was better when more points were used to estimate the parameters. Also, the Gompertz model underestimated plant height values in the initial period for all situations studied (Figure 1 A-D), being the Logistic model preferable to describe the height growth of the Rhino sunflower cultivar.

As the Logistics model best fits the data, only the critical points generated by this model will be considered. The estimated critical points are shown to be important helpers in crop management. Approximately $21.10 \%$ of the asymptote occurs when MAP is reached; $50.00 \%$ when IP is reached; $78.80 \%$ when MDP is reached; and $90.80 \%$ when ADP is reached (MISCHAN \& PINHO, 2014). MAP values show plant growth becomes positive and growing from $41.707 \mathrm{~cm}$ and $486.545^{\circ} \mathrm{C}, 40.587 \mathrm{~cm}$ and $504.587^{\circ} \mathrm{C}, 42.871 \mathrm{~cm}$ and $542.138{ }^{\circ} \mathrm{C}$ accumulated for the first, second and third trials, respectively (Table 1). This indicator is important because in the initial period, before MAP, plants have less growth capacity and; consequently, less ability to compete with spontaneous plants, requiring greater care with weed control up to this point. This observation corroborates studies by BRIGHENTI et al. (2004) and BRIGHENTI (2012), who reported that they are necessary for the plant to express all its productive potential, about 30 days after emergence free of weed plants, as they cause growth reduction, chlorosis and decrease in leaf area, stem diameter, chapter and achenes yield.

When IP is reached, the curve changes in the concavity and the growth rate starts to decrease (FERNANDES et al., 2014; JANE et al., 2020). In this study, the height values for the IP were $98.679 \mathrm{~cm}$, $96.029 \mathrm{~cm}$ and $101.433 \mathrm{~cm}$ with687.964 ${ }^{\circ} \mathrm{C}, 677.780$ ${ }^{\circ} \mathrm{C}$ and $749.283{ }^{\circ} \mathrm{C}$ accumulated for the first, second and third trials, respectively. According to LOBO et al. (2013), nitrogen and potassium are the nutrients that most limit sunflower production, and from 28 to 56 days after emergence, a period that can be compared to the MAP and IP interval, there is a rapid increase in nutritional demand. Still, VALADÃO et al. (2020), recommend installment applications of boron at 15, 30 and 45 days after sowing, and nitrogen at 30 days after emergence to achieve higher yields. Therefore, fertilizer coverage applications would have optimized results if they were carried out between MAP and IP range.

The plant height values observed in the ADP were $179.262 \mathrm{~cm}, 174.410 \mathrm{~cm}$ and 187.237

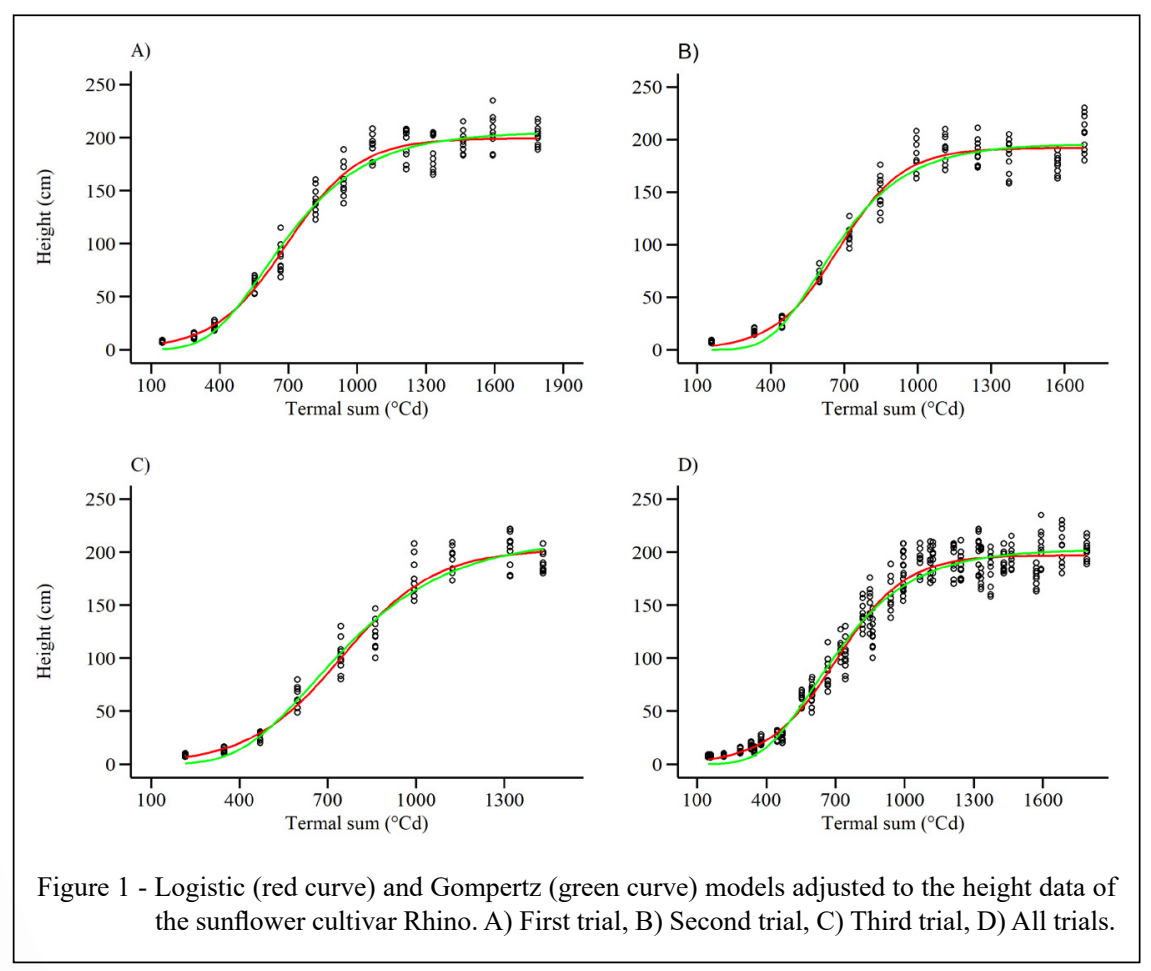

Ciência Rural, v.52, n.3, 2022. 
1 cm with $1038.632{ }^{\circ} \mathrm{C}, 979.566{ }^{\circ} \mathrm{C}$ and $1109.068{ }^{\circ} \mathrm{C}$

2 accumulated for the first, second and third trials,

3 respectively. According to UCHÔA et al. (2011), the

4 smaller stature of plants is associated with precocity,

5 which gives plants a shorter period of development.

6 Still, the short stature of plants makes it possible to

7 reduce the spacing in future crops, which would assist

8 in the control of weeds (AMABILE et al., 2003). The

9 ADP can be used as amaturity indicator since when

10 reaching this point plants start growth stabilization

11 and can be harvested for producing silage without

12 volume loss and with higher quality, as the flowering

13 phase would be complete (R6 stage), being suitable

14 for silage production (TAN, 2010).

15

16

17

18

19

20

\section{CONCLUSION}

The models show differences between the trials. The Logistic model has a better fit quality, being the most suitable for characterizing the growth curve of the sunflower confectionery cultivar in height. The estimated critical points provide important information for crop management. Weeds must be controlled until the maximum acceleration point. Covered fertilizer applications must be carried out between the maximum acceleration and inflection points. Asymptotic deceleration point is an indicator of maturity, after reaching this point the plants can be harvested for the production of silage without loss of volume and quality.

\section{DECLARATION OF CONFLICT OF} INTEREST

The authors declare no conflict of interest. The founding sponsors had no role in the design of the study; in the collection, analyses, or interpretation of data; in the writing of the manuscript, and in the decision to publish the results.

\section{ACKNOWLEDGEMENTS}

To the Conselho Nacional de Desenvolvimento Científico e Tecnológico $(\mathrm{CNPq})$, to the Fundação de Amparo à Pesquisa do Estado do Rio Grande do Sul - FAPERGS andtothe Fundação Universidade Federal de Santa Maria - Frederico Westphalen for scholarships. To the FAPERGS/CNPq by financial support (Process number 16/2551-0000257-6 ARD/PPP). To the Coordenação de Aperfeiçoamento de Pessoal de Nível Superior (CAPES), Brasil, by financial support- Financecode 001

\section{AUTHORS' CONTRIBUTIONS}

MT designed and supervised the experiment. ACM, RRS, JCS, VM and ACVP performed the experiments and data collection. ACM performed the statistical analyses. ACM and MT prepared the draft of the manuscript. All authors critically revised the manuscript and approved the final version.

\section{REFERENCES}

AKAIKE, H. A new look at the statistical model identification. IEEE Transactions on Automatic Control, v.19, p.717-723, 1974. Available from: <https://doi.org/10.1109/TAC.1974.1100705>. Accessed: May, 14, 2021. doi: 10.1109/TAC.1974.1100705.

ALVARES, C. A et al. Köppen's climate classification map for Brazil. Meteorologische Zeitschrift, v.22, n.1, p.711-728, 2013. Available from: <https://doi.org/10.1127/0941-2948/2013/0507>. Accessed: Mar. 08, 2021. doi: 10.1127/0941-2948/2013/0507.

AMABILE, R. F. et al. Growth analysis of sunflower in a Cerrado Oxisol with different levels of basis saturation. Pesquisa Agropecuária Brasileira, v.38, n.2, p.219-224, 2003. Available from: <https://doi.org/10.1590/S0100204X2003000200008>. Accessed: May, 15, 2021. doi: 10.1590/ S0100-204X2003000200008.

AMORIM, D. S. et al. Fermentation profile and nutritional value of sesame silage compared to usual silages. Italian Journal of Animal Science, v.19, n.1, p.230-239, 2020. Available from: $<$ https://doi.org/10.1080/1828051X.2020.1724523>. Accessed: Mar. 05, 2021. doi: 10.1080/1828051X.2020.1724523.

ARNOLD, C. T. The determination and significance of the base temperature in a linear heat unit system. Proceedings of theAmerican Society for Horticultural Science, v.74, p.430$455,1959$.

BATES, D. M.; WATTS, D. G. Nonlinear regression analysis and its applications. New York: John Wiley \& Sons, 1988.

BEM, C. M. et al. Growth models for morphological traits of sunn hemp. Semina: Ciências Agrárias, v.38, n.5, p.2933-2943, 2017. Available from: <https://doi.org/10.5539/jas.v10n1p225>. Accessed: Jan. 05, 2021. doi: 10.5539/jas.v10n1p225.

BREUSCH, T.; PAGAN, A. A simple test for heteroscedasticity and random coefficient variation. Sociedade Econométrica, v.47, p.1287-1294, 1979. Available from: <http://dx.doi. org/10.2307/1911963>. Accessed: May, 14, 2021. doi: $10.2307 / 1911963$.

BRIGHENTI, A. M. Sunflower resistance to acetolactate synthaseinhibiting herbicides. Pesquisa Agropecuária Tropical, v.42, n.2, p.225-230, 2012. Available from: $<$ https://doi.org/10.1590/S198340632012000200014>. Accessed: Jan. 23, 2021 doi: 10.1590/ S1983-40632012000200014.

BRIGHENTI, A. M. et al. Interference periods of weeds in sunflower crop. Planta Daninha, v.22, n.2, p.251-257, 2004. Available from: $<$ https://doi.org/10.1590/S0100-83582004000200012>. Accessed: Mar. 16, 2021 doi: 10.1590/S0100-83582004000200012.

CARINI, F. et al. Nonlinear models for describing lettuce growth in autumn-winter. Ciência Rural, v.50, n.7, e20190534, 2020. Available from: <https://dx.doi.org/10.1590/01038478cr20190534>. Accessed: Jan. 05, 2021. doi: 10.1590/0103$8478 \mathrm{cr} 20190534$

CONAB - Companhia Nacional de Abastecimento. Acompanhamento da safra brasileira 2019/2020. Acompanhamento da Safra Brasileira de Grãos 2019/2020, 2020. p.1-29. Available from: <https://www.conab.gov.br/info-agro/ safras/graos $>$. Accessed: Jan. 01, 2021. 
CQFS - Comissão de química e fertilidade do solo. Sociedade Brasileira de Ciência do Solo. Manual de calagem e adubação para os Estados do Rio Grande do Sul e de Santa Catarina. Núcleo Regional Sul, 2016, 376p. Available from: $<$ https://www.sbcs-nrs.org. br/index.php?secao=publicacoes $>$. Accessed: Jun. 13, 2021.

DIEL, M. I. et al. Behavior of strawberry production with growth models: A multivariate approach. Acta Scientiarum - Agronomy, v.43, p.1-11, 2021. Available from: <https://doi.org/10.4025/ actasciagron.v43i1.47812>. Accessed: Feb. 04, 2021. doi: 10.4025/ actasciagron.v43i1.47812.

DURBIN, J.; WATSON, G. S. Testing for serial correlation in least squares regression: I. Biometrika, v. 37, n. 3/4, p. 409-428, 1950. Available from: $<$ https://doi.org/10.2307/2332391 $>$. Accessed: May, 14, 2021. doi: 10.2307/2332391.

FERNANDES, T. J. et al. Selection of nonlinear models for the description of the growth curves of coffee fruit. Coffee Science, v.9, n.2, p.207-215, 2014. Available from: <https://doi.org/10.25186/ cs.v9i2.618>. Accessed: Feb. 25, 2021. doi: 10.25186/cs.v9i2.618.

GILMORE, E. C.; ROGERS, J. S. Heat units as a method of measuring maturity in corn. Agronomy Journal, v.50, p.611615, 1958. Available from: <https://doi.org/10.2134/agronj19 58.00021962005000100014x>. Accessed: Jan. 22, 2021. doi: $10.1080 / 14620316.2018 .1472045$.

HESAMI, S. M. et al. Enhanced biogas production from sunflower stalks using hydrothermal and organosolv pretreatment. Industrial Crops and Products, v.76, p.449-455, 2015. Available from: $<$ http://dx.doi.org/10.1016/j.indcrop.2015.07.018>. Accessed: Jan. 05, 2021. doi: 10.1016/j.indcrop.2015.07.018.

HLADNI, N. et al. Interdependence of yield and yield components of confectionary sunflower hybrids. Genetika, v.43, n.3, p.583-594, 2011. Available from: <http://dx.doi.org/10.2298/ GENSR1103583H>. Accessed: Mar. 10, 2021. doi: 10.2298/ GENSR1103583H.

HLADNI, N. et al. Correlation and path analysis of yield and yield components of confectionary sunflower. Genetika, v.48, n.3, p.827-835, 2016.Available from: <http://dx.doi.org/10.2298/ GENSR1603827H>. Accessed: Mar. 10, 2021. doi: 10.2298/ GENSR1603827H.

IRAM, S. et al. Helianthus annuus based biodiesel production from seed oil garnered from a phytoremediated terrain. International Journal of Ambient Energy, v.0, n.0, p.1-9, 2020. Available from: $<$ https://doi.org/10.1080/01430750.2020.1722228>. Accessed: Feb. 08, 2021. doi: 10.1080/01430750.2020.1722228.

JANE, S. A. et al. Adjusting the growth curve of sugarcane varieties using nonlinear models.Ciência Rural, v.50, n.3, p.1-10, 2020 Available from: <https://doi.org/10.1590/0103-8478cr20190408>. Accessed: Feb. 08, 2021. doi: 10.1590/0103-8478cr20190408.

KLEINPAUL, J. A. et al. Productive traits of rye cultivars grown under different sowing seasons. Revista Brasileira de Engenharia Agrícola e Ambiental, v.23, n.12, p.937-944, 2019. Available from: <http://dx.doi.org/10.1590/1807-1929/agriambi. v23n12p937-944>. Accessed: Mar. 11, 2021. doi: 10.1590/18071929/agriambi.v23n12p937-944.

KOUTROUBAS, S. D. et al. Sunflower growth and yield response to sewage sludge application under contrasting water availability conditions. Industrial Crops and Products, v.154, p.112670, 2020. Available from: <https://doi.org/10.1016/j. indcrop.2020.112670>. Accessed: Mar. 11, 2021. doi: 10.1016/j. indcrop.2020.112670.

LOBO, T. F. et al .Effect of sewage sludge and nitrogen on production factors of sunflower. Revista Brasileira de Engenharia Agrícola e Ambiental, v. 17, n.5, p.504-509, 2013. Available from: $<$ https://doi.org/10.1590/S1415-43662013000500006>. Accessed: May, 17, 2021. doi: 10.1590/S1415-43662013000500006.

MAZZINI, A. R. de A. et al. Growth curve analysis for Herefordcattle males. Ciência e Agrotecnologia, v.27, n.5, p.1105-1112, 2003. Available from: <https://doi.org/10.1590/ S1413-70542003000500019>. Accessed: Jan. 09, 2021. doi: $10.1590 / \mathrm{S} 1413-70542003000500019$.

MISCHAN, M.M. et al. Determination of a point sufficiently close to the asymptote in nonlinear growth functions. Scientia Agricola, v.68, p.109-114, 2011. Available from: $<$ https://doi.org/10.1590/ S0103-90162011000100016>. Accessed: Jan. 09, 2021. doi: 10.1590/S0103-90162011000100016.

MISCHAN, M. M.; PINHO, S. Z. Modelos não lineares: funções assintóticas de crescimento. Cultura Acadêmica: São Paulo, 2014.

MUNIZ, J. A. et al. Nonlinear models for description of cacao fruit growth with assumption violations.Revista Caatinga, v.30, n.1, p.250-257, 2017. Available from: <https://doi.org/10.1590/198321252017v30n128rc $>$. Accessed: Mar. 12, 2021. doi: 10.1590/1983-21252017v30n128rc.

PEKCAN, V. et al. Developing confectionery sunflower hybrids and determination of their yield performances in different environmental conditions. Ekin Journal of Crop Breeding and Genetics, v.1, n.2, p.47-55, 2015. Available from: <https:// dergipark.org.tr/tr/pub/ekinjournal/issue/22786/243178>. Accessed: Mar. 12, 2021.

PIVETTA, L. G. et al. Evaluation of sunflower hybrids and the relationship between productive and qualitative parameters. Revista Ciência Agronômica, v.43, n.3, p.561-568, 2012. Available from: <https://dx.doi.org/10.1590/S180666902012000300020>. Accessed: Mar. 10, 2021. doi: 10.1590/ S1806-66902012000300020.

R DEVELOPMENT CORE TEAM. R: A language and environment for statistical computing. $\mathbf{R}$ Foundation for Statistical Computing. Vienna, Austria, 2020. Available from $<$ http://www.R-project.org/>. Accessed: Feb. 21, 2021.

RITZ, C.; STREIBIG, J.C. Nonlinear regression with R. Springer, New York, 2008. 142p.

SARI, B. G. et al. Nonlinear growth models: An alternative to ANOVA in tomato trials evaluation. European Journal of Agronomy. v.104, p.21-36, 2019. Available from: <https://doi. org/10.1016/j.eja.2018.12.012>. Accessed: Feb. 02, 2021. doi: 10.1016/j.eja.2018.12.012.

SCHWARZ, G. Estimating the Dimension of a Model. The Annals of Statistics, v.6, p,461-464, 1978. Available from: <http://www. jstor.org/stable/2958889>. Accessed: May, 14, 2021.

SEBER, G.A.F. Linear Regression Analysis. New York: John Wiley, 2003. 2ed., 557p.

Ciência Rural, v.52, n.3, 2022. 
SENTELHAS, P.C. et al. Base-temperature and degree-days to cultivars of sunflower. Revista Brasileira de Agrometeorologia v.2, n.1, p.43-49, 1994. Available from: <http://www.sbagro.org/ files/biblioteca/37.pdf $>$. Accessed: Feb. 08, 2021.

SHAPIRO, S. S.; WILK, M. B. An analysis of variance test for normality. Biometrika, v.52, p.591-611, 1965. Available from: $<$ http://dx.doi.org/10.2307/2333709>. Accessed: May, 14, 2018. doi: $10.2307 / 2333709$.

STRECK, N. A. et al. Modeling leaf appearance in cultivated rice and red rice. Pesquisa Agropecuária Brasileira, v.43, p.559-567, 2008. Available from: $\quad<$ http://dx.doi.org/10.1590/S0100-204X2008000500002>. Accessed: Jan. 20, 2021. doi: S0100-204X2008000500002.

TAN, A. S. Sunflower (Helianthus annuus L.) researches in the Aegean region of Turkey. Helia, v.33, n.53, p.77-84, 2010. Available from: <https://doi.org/10.2298/HEL1053077T>. Accessed: Jan. 20, 2021. doi: 10.2298/HEL1053077T.

UCHÔA, S. C. P. et al. Potassium fertilization in side dressing in the yield components of sunflower cultivars. Revista Ciência Agronômica, v. 42, n. 1, p. 8-15, 2011. Available from: <https:// doi.org/10.1590/S1806-66902011000100002>. Accessed: May, 15, 2021. doi: 10.1590/S1806-66902011000100002.
VALADÃO, F. C. A. et al. Sunflower productivity in function of the management of nitrogen fertilization. Brazilian Journal of Development, v.6, n.11, p.84197-84213, 2020. Available from: $<$ https://doi.org/10.34117/bjdv6n10-744>. Accessed: May, 17, 2021. doi: 10.34117/bjdv6n10-744.

WHEELER, M. W. et al. Comparing median lethal concentration values using confidence interval overlap or ratio tests. Environmental Toxicology and Chemistry, v.25, p.1441-1444, 2006. Available from: <http://dx.doi. org/10.1897/05-320R.1>. Accessed: Jan. 20, 2021. doi: 10.1897/05-320R.1.

YANKOV, B.; TAHSIN, N. Genetic variability and correlation studies in some drought-resistant sunflower (Helianthus annuus L.) genotypes. Journal of Central European Agriculture, v.16, n.2, p.212-220, 2015. Available from: < http://dx.doi.org/10.5513/ JCEA01/16.2.1611>. Accessed: Jan. 21, 2021. doi: 10.5513/ JCEA01/16.2.1611.

ZEVIANI, W. M. et al. Non linear models topotassium release from animals manure in Latosols. Ciência Rural, v.42, n.10, p.1789-1796, 2012. Available from: <https://doi.org/10.1590/ S0103-84782012001000012>. Accessed: Feb. 21, 2021. doi: $10.1590 / \mathrm{S} 0103-84782012001000012$. 